IdeAs

Idées d'Amériques

$17 \mid 2021$

Villes et culture dans les Amériques

Jody Cardinal, Deirdre E. Egan-Ryan, and Julia Lisella (eds.), Modernist Women Writers and American Social Engagement

Lexington Books, 2019, 315 pages

Johanna M. Wagner

\title{
OpenEdition
}

Journals

Electronic version

URL: https://journals.openedition.org/ideas/10541

DOI: 10.4000/ideas. 10541

ISSN: 1950-5701

Publisher

Institut des Amériques

Electronic reference

Johanna M. Wagner, "Jody Cardinal, Deirdre E. Egan-Ryan, and Julia Lisella (eds.), Modernist Women

Writers and American Social Engagement", IdeAs [Online], 17| 2021, Online since 01 March 2021,

connection on 07 June 2021. URL: http://journals.openedition.org/ideas/10541 ; DOI: https://doi.org/ 10.4000/ideas. 10541

This text was automatically generated on 7 June 2021.

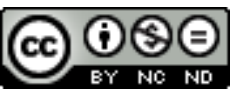

IdeAs - Idées d'Amériques est mis à disposition selon les termes de la licence Creative Commons Attribution - Pas d'Utilisation Commerciale - Pas de Modification 4.0 International. 


\section{Jody Cardinal, Deirdre E. Egan-Ryan, and Julia Lisella (eds.), Modernist Women Writers and American Social Engagement}

Lexington Books, 2019, 315 pages

Johanna M. Wagner

\section{REFERENCES}

Jody Cardinal, Deirdre E. Egan-Ryan, and Julia Lisella (eds.), Modernist Women Writers and American Social Engagement, Lexington Books, 2019, 315 pages

1 The "new modernist studies", coined by Mao and Walkowitz in their titular article in the May 2008 issue of PMLA, has been a boon for scholars who study women writers. As modernism has "softened its definitional gaze and relinquished its gatekeeping function" (451), as stated by Paul Saint-Amour in 2018, its scholarship has blossomed in variation and kind. An interest in gender, i.e. women writers, a long-policed, tacit demarcation in literary modernism, has increased and continues to prosper in this newly hospitable terrain. Still, to see a full-length book about American modernist women writers continues to surprise and excite, even in the $21^{\text {st }}$ century.

2 No matter how far women authors have come in English literary studies, an anthology focused on women modernists is a cause for celebration. If nothing else, it suggests that the authors assessed in the collection might be studied and explored at the highest levels of academia for at least another day. For one is always concerned women's authorship may be neglected, and women's literary production ignored; one must always be on the lookout for the dire consequences of outright dismissal of women's work by its falling out of print. As observed by Jane Garrity in her 2008 review of Bonnie Kime Scott's Gender in Modernism (2007), when handling women's literature, one 
can never rest assured that the authors one reads and writes about today will be available for reading and writing about tomorrow (806). Hence, each new collection of scholarship focused on women writers elicits a sense of hope, an anticipation that the subject matter will increase the staying power of these authors.

3 Collections focused on women writers in modernism, I suggest, have been "new modernist", even before the term existed. For, women modernist writers and sympathetic critics have always broadened the borders of modernism, even while only attempting to be included within them. Therefore, the collection being reviewed exists in this dualism: attempting to illustrate simultaneously that women writers are "modernist", but also opening wide the idea of "modernism" itself. This collection is a striking array of arguments focused on the connection of American women writers and their modernist social engagement. The beauty of this collection, like many that have come before, is the way in which lesser known, unknown, and under-researched authors are brought to the fore, while well-known authors are resituated in order to be examined in a new light. This book in its entirety is an argument for the elevation of cross-disciplinarity - especially history and culture studies - in literary studies; it is a petition for broadening the boundaries of modernist studies, and it is a testament to how women's literature itself has become critical to the ambitions of the new modernist studies.

4 Editors Jody Cardinal, Deirdre E. Egan-Ryan, and Julia Lisella do an impressive job of contextualizing the sections of their book Modernist Women Writers and American Social Engagement in an indispensable introduction. For themselves, they firmly state their main goal is to advance "three critical traditions" of American women's modernist literature: recovery, further study, and connecting American modernist literature with cultural studies (4). Through these goals, they suggest the book examines if American women writers were cognizant of "racism, immigration, imperialism" and socioeconomic inequality "unbounded by national borders" (2). As can be seen by the section outline, and observations noted further in the review, these writers were obviously aware of and engaged shrewdly in the global conversations related to these various issues. The four sections: 1. Women's Work as Modernist Engagement. 2. Modernism, Social Movements and Advocacy. 3. Political Radicals and Modernism. 4. Modernist Social Engagement in Its Global Context, all exhibit a consciousness of the problems of modernity on the one hand, and cover imperative aspects of modernism that continue to be under-researched on the other.

5 The sections differ in nature and scope, as do the chapters; therefore, like a true anthology, I assumed this text would most likely not be read cover to cover, but would be sought out piecemeal, for specific nuggets of inspiration peculiar to the author or subject one is researching. With that said, however, I did find myself reading, with relish, chapters that, by title alone, I would not have thought align with my own research interests. For example, Julia Lisella's chapter on Genevieve Taggard's poems of Hawai'i was an inspiration. I had only known Taggard's name in passing; therefore, it was surprising to learn the importance of her work, not only her poetry, but her travel writing, to early twentieth-century Americans on the mainland curious about the fiftieth state. Her use of Hawaiian mythology for inspiration that paralleled the Greek and Latin myths found in other modernist work was exciting to learn, as was her nearpostmodern comprehension of the quasi-hybrid balancing act she had to play in honoring a land and culture she was raised in, but was not a part of in many significant 
ways (Taggard was a white woman in Polynesian culture). There were other chapters that surprised and inspired in similar ways - either by introducing an unknown or little-known author, and/or by finding unique and stimulating new ways of reading modernist techniques - such as Laura Dawkins chapter on Harlem Renaissance author and playwright Marita Bonner, whose one-act play The Purple Flower Dawkins describes as a modernist exploration of interconnectedness in the African American community, in which questions of gender and racial unity exist alongside honoring the past (slave resistance) and revolutionizing a new future. Also, Amanda J. Zink's chapter on the Hopi writer Polingaysi Qoyawayma's autobiography, which Zink sees as a refiguring of modernist technique: a postcolonial subject synthesizing new with old in a blending of "elements, practices, customs [...] habits" of at least two cultures, otherwise named syncretic modernism (68). I can only assume (and hope) other readers will have similar experiences of delight and inspiration upon encountering equally surprising morsels.

This collection has a vast difference in subject matter. As noted earlier, there are familiar names such as Gertrude Stein, Mina Loy, Edna St. Vincent Millay, Elizabeth Bishop, Marianne Moore or Katherine Anne Porter. All are approached in refreshing new ways: for example, lesser-known works are illuminated by new cultural and political light, which invigorates the existing modernist critical work on such authors (Stein, Loy, and Millay); a spotlight is placed on the modern interconnections between publication and world politics (Bishop and Moore); and long-studied texts are couched firmly in the modernist present, where representations of the psyche are linked to political/moral crises (Porter). Alongside these recognizable writers, other authors, under-researched and perhaps unknown to many, are introduced amidst a sense of modern regeneration. For example, in two chapters a re-working of the motivation and aims of sentimentalism in modernism (Virginia Lee Burton and Lola Ridge), a revitalized activism attributed to modern epistolary writing (Anne Spencer), and a reaffirmation of the modernist tendencies in popular working-class fiction writers (Edna Ferber and Mary Robert Rinehart). In all, the array of subjects and writers is vast, but the ambitions are similar: introduce, in some cases, remind, in others, that modern women's writing has always been more connected to the now, the political, social, economic, cultural, national and global world than they have ever been given credit for.

7 Generally structured from engagement to activity, to radicalism and to the global stage, the book maintains an appropriately stimulating progression from inside to outside: a strong centrifugal thrust directed by increasing levels of social interaction associated with literary production. This outward development brings with it an intensifying sense of urgency escalating a wider and wider reach with each chapter, a satisfying journey for the reader intent on an inclusive understanding of American literary modernism in a global context.

8 To end, I want to return to the editors' three major objectives for this collection: the recovery of American women writers, the further study of American women writers, and connecting American women's modernist literature with cultural studies. In light of these goals and of the remarkable and stimulating work they have commissioned to meet them, this reviewer congratulates them on an admirable success. 


\section{BIBLIOGRAPHY}

Garrity, Jane, "Found and Lost: The Politics of Modernist Recovery," Modernism/modernity, vol. 15, $n^{\circ}$ 4, November 2008, p. 803-12.

Mao, Douglas and Rebecca L. Walkowitz, “The new Modernist Studies?" PMLA, vol. 123, n 3, May 2008, p. 737-48.

Saint-Amour, Paul K, “Week Theory, Weak Modernism?” Modernism/modernity, vol. 25, n 3, September 2018, p. 437-59.

\section{AUTHORS}

JOHANNA M. WAGNER

Østfold University College, Norway 